\title{
Identification of Public Satisfaction on Quality of Website Design Online Musrenbang of Surabaya City Related To Participatory Planning Process
}

\author{
Luluk Harida Budianti \\ Department of Architecture \\ Sepuluh November Institute of Technology
}

\author{
Adjie Pamungkas \\ Department of Urban and Regional Planning \\ Sepuluh November Institute of Technology
}

\author{
Eko Budi Santoso \\ Department of Urban and Regional Planning \\ Sepuluh November Institute of Technology
}

\begin{abstract}
The city of Surabaya seeks to apply the concept of good governance based on e-government by involving the participation of its community to convey the aspirations and participate in the annual city development planning process online through Online Musrenbang. When viewed from the substance of participatory planning there are some shortcomings in the design of Online Musrenbang which causes the process of participatory development planning Surabaya is not currently in the category of 'genuine participation' stage. Therefore it is necessary to conduct research of public satisfaction on quality of website design of online Musrenbang of surabaya city related to participatory planning process to identification the shortcomings. This study uses a rationalistic approach with the quantitative research. A descriptive analysis method and scoring is used to identify public satisfaction based on answer result of the questionnaire from RW team as end user non-pemrograman.The conclusion is the public satisfaction on quality of website design of Online Musrenbang of surabaya city related to participatory planning process to identification can be identification as 'Less Satisfactory'. Therefore, all variables can be categorized as something that needs to be developed to increase people's satisfaction with this web-based application.
\end{abstract}

Keywords: Development Planning, Participatory Planning, E-Government, Human-Computer Interaction, EMusrenbang, Musrenbang Online.

\section{INTRODUCTION}

The government of Surabaya city involves the participation of its community in the annual city development planning process or the onlie of Development Planning Meeting (Musyawarah Perencanan Pembangunan-Musrenbang) or eMusrenbang. The Online Musrenbang through website http://musrenbang.surabaya.go.id/musrenbang/ created and matured concept in 2008. This web-based application can start operationalized in 2009 until now [1]. The implementation of e-Musrenbang aims to facilitate the citizens to know the incoming proposal which is then verified by the musrenbang team and recapitulate the proposal more quickly and efficiently online [2].

The study related to the effectiveness of Online-based participatory planning in East Surabaya stated that Online Musrenbang pertained in the very effective category with the achievement level of public planning at the level of placation [1]. The existence of Online Musrenbang is considered to have been able to accommodate ideas from the community to resolve issues that exist in the environment. Communities are involved in the process of determining the proposed development activities without intervention from the government, since the selection stage in Rukun Warga - RW (similar with hamlet) as the lowest level to Kelurahan (similar with urban village), Kecamatan (similar with sub-district), until Satuan Kerja Pemerintah Daerah - SKPD (the local government work units) of Surabaya. Percentage of community proposals that will be used as a material for consideration by the municipality to be implemented in urban development up to $50 \%$. Besides, the public can also monitor their proposals directly or online.

The quality of the e-Government website affects the participation of the community to use the services provided [3]. Meanwhile, there are some shortcomings in the website design of Online Musrenbang that cause the process of participatory development planning is still at the level of placation [1]. First, the community cannot know the task and authority of each stakeholder in Online Musrenbang. Then, they cannot know the priority of Surabaya City development plan. They did not know about the macro policy of each local government work units (SKPD) also. The public cannot claim the truth of the policy shown on Online Musrenbang. The community has not been able to understand which proposal is suitable with the local government work units (SKPD) policy, so that it can accepted as a proposal in musrenbang. They cannot be involved in decision making to determine the priority proposal. They also cannot monitor and evaluate the implementation of Online Musrenbang result. Community participation in musrenbang still stages at the level of information and consultation, where the community is involved in the stages of gathering proposals and accommodating proposals that arise from the community [2]. The community for the implementation of Musrenbang has not been comprehensive and is still a formality of annual routine activities [4].

The purpose of Musrenbang is involving the participation of the community to know the development plan that will be carried out as stipulated in Law no. 25 of 2004 on National Development Planning System (Undang No. 25 Tahun 2004 tentang Sistem Perencanaan Pembangunan Nasional). The method of development planning involving citizens as the subject of development is participatory planning [5]. In this 
study, the aspects that influence the successful implementation of participatory planning are the accessibility of information, community involvement, transparency and justice, accountability, and the role of local government.

The Online Musrenbang is an e-government application related to participatory planning. This is suitable with the form of electronic participation (E-Participation) and Open Government that has changed the perspective of how people interact and demonstrate ongoing participation with real impact on how public services are delivered in the internet era [6]. Institution-based trust, audience, quality of e-government services, usage, and website design are aspects that influence the success of e-government use in this research.

The quality of the e-government website affects the participation of the community to use the services provided [3]. There is a significant positive relationship between the qualities of government websites towards the public's desire to use the egovernment services offered. Thus, the aspects of human and computer interaction in website design that affect the success of e-government implementation in this research are related to website quality which includes the user interface quality, usability quality, and website information quality.

In this research, the quality of the Online Musrenbang website design related to participatory planning process was identified based on the following aspects. Those are information accessibility, user interface design of the website, usage of the website and website content.

\section{METHODOLOGY}

This research uses a rationalistic approach that occupies a specific object in holistic totality [7]. The research method used quantitative which is a research method for obtaining data in the form of numbers or qualitative data that is suspected [8]. While the sampling technique using stratified random sampling that proportional appropriate with the proposed [9]. The population, in this case, is the chairman of entire RW present in Surabaya appropriate with their involvement in Online Musrenbang as the end user which incorporates the proposed community who have agreed on the RW level into the website of Online Musrenbang. End users in this study are nonprogramming end users who only use software that has been created by others, have little or no computer literate, communicate with hardware using the help menu and rely on others to give technical assistance [10]. The population was divided into strata by region, namely: Surabaya Center, North Surabaya, East Surabaya, South Surabaya and West Surabaya with the required sample size calculated based on Slovin's formula [8]. Therefore, from 1365 there were approximately 100 RW's which were then taken by 13 from Central Surabaya, 16 from North Surabaya, 23 from East Surabaya, 26 from South Surabaya and 23 from West Surabaya.

Data were collected by using questionnaires on selected respondents. The used analysis method is descriptive and skoring. Descriptive analysis is used to provide an overview of website Online Musrenbang in depth based on the existing condition and become the focus of research through an observation related to the level of community satisfaction on the quality of website design of Online Musrenbang related to the process of participatory planning.

\section{THE HISTORY OF ONLINE MUSRENBANG APPLICATION DEVELOPMENT}

In order for the musrenbang process to be more effective and efficient, the government of Surabaya City develops webbased musrenbang that is Online Musrenbang or eMusrenbang. Applications that have been operated since 2009 until now is still very open to being developed so that more open access community to Musrenbang. Especially from application changes that occur from year to year since the implementation of 2016 Musrenbang increasingly reduce access of Surabaya residents to participate in Musrenbang. The changes of feature application from time to time are as follows:

1. Filling proposals since 2014 can be done from the RW level, where during the implementation period of 2009 2013 the proposal submission is done at the RW level. Although in 2018, replenishment of proposals was made back to the kelurahan level. However, there is still information that the proposal is the result of the participation of a particular of the RW.

2. The GIS-based for Proposal Map in 2014, so that incoming proposals can be mapped in the form of dots and lines on the map of Surabaya with information that can be accessed when the user clicks the object. However, by 2018 this feature could not access by public.

3. The user's vote and feedback feature as an effort to involve community or individual participation related to the approved proposal presented in the GIS base is in 2016 . However, in 2017 this feature is no longer exists.

4. The 'Online FAQ' feature is added in the Online Musrenbang in 2016 . However, by 2017 , this feature is no longer exists.

\section{RESULT AND DISCUSSION}

In this study, there are four indicators with 20 variables related to the level of satisfaction of respondents to website design Online Musrenbang related participatory planning process compiled from the research variables. The indicators and variables are as follows:

- The first indicator relates to the accessibility of information with 2 variables, namely: the socialization intensity of Musrenbang activities in detail and the ease for the user to access information of Musrenbang activities through Online Musrenbang website

- The second indicator relates to user interface design of the website with 6 variables, namely: interactive interface, the functionality of feature for channeling community aspiration, the functionality of feature for the resource from society, the functionality of feature for decision making, the functionality of monitoring and evaluation features at the implementation of Musrenbang.

- The third indicator relates to usage of the website with 3 variables, namely: the ease of application usage, the application responsibility and the interaction with service officers (interactive).

- The fourth indicator relates to content of the website with 9 variables, namely: reliability of the information presented, relevance to the topic of development planning, presentation of information related to Online Musrenbang compatibility of Online Musrenbang with all applicable 
regulations, government appreciation for community participation in the development planning process, presentation of information on how to use the application, presentation of sustainable planning information, presentation of community-focused planning information, presentation of feasibility planning information, presentation of Musrenbang data information

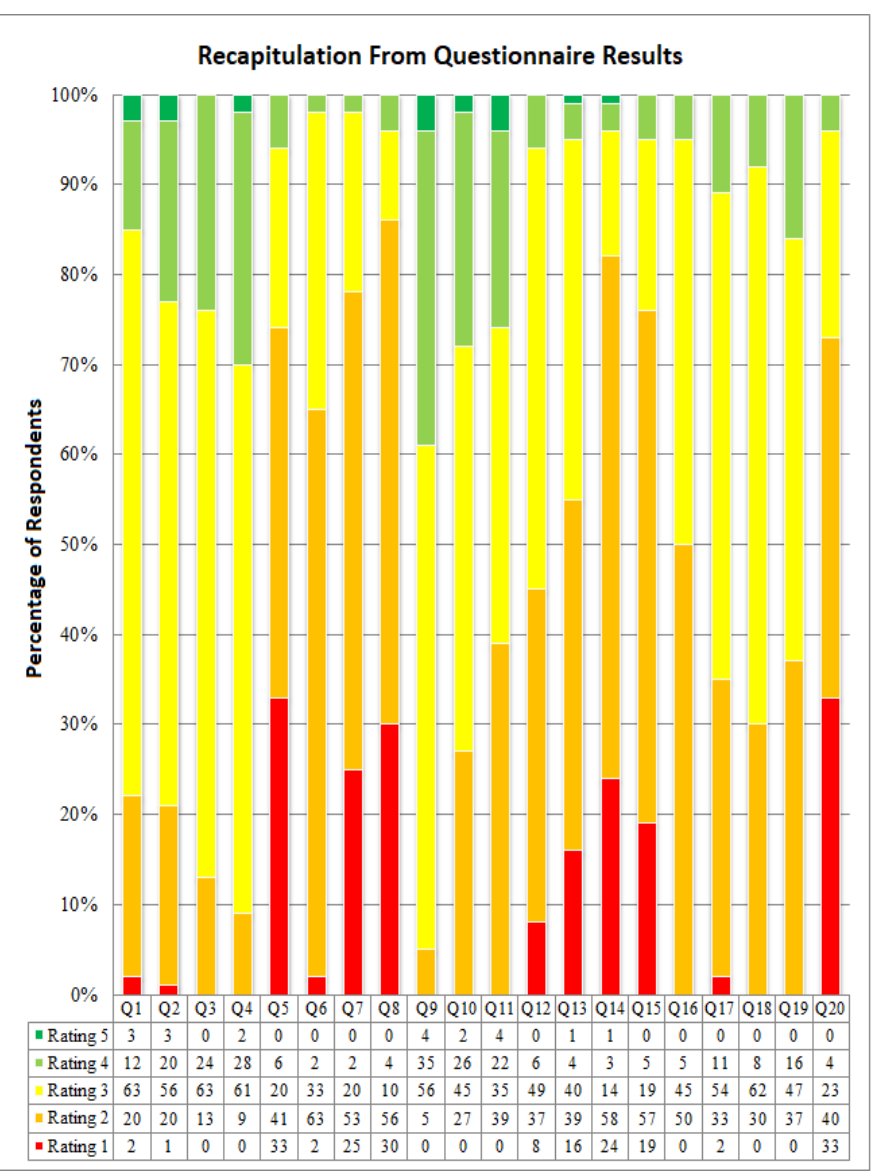

Fig. 1. Recapitulation of answers from questionnaires that distributed to 100 respondents (RW Team) in the bar chart

Data collection in this study was conducted on selected respondents by using online questionnaire that contain of 20 questions. It has also been prepared with limited or directed answers in 5 multiple choices, namely: Very Unsatisfactory, Unsatisfactory, Less Satisfying, Satisfactory and Very Satisfactory. The bar chart of the answers recapitulation from questionnaires that distributed to 100 respondents presented in Fig 1.

The answers from the respondents were assessed using a scoring technique that has been processed [11]. From the results of the scoring, the process can be seen that the variable is regarded as a problem or not. Thus the description of the problems in the website design Online Musrenbang.

The results of the identification of quality on the Online Musrenbang (e-Musrenbang) design are related to the participatory planning process through questionnaires distributed to 100 respondents of RW Team as outlined in Table I. It can be seen that the community declares the quality of Online Musrenbang website from 'Unsatisfactory' to 'Satisfactory'. The range of index values for each category are as follows [11]:
- Unsatisfactory is about 20-39.9.

- Less Satisfactory is about 40-59.9.

- Satisfactory is about 60-79.9.

TABLE I. COMMUNITY SATISFACTION ON THE QUALITY PN ONLINE MUSRENBANG WEBSITE DESIGN RELATED TO THE PARTICIPATORY PLANNING PROCESS

\begin{tabular}{|c|c|c|c|}
\hline Q & Variable & $\begin{array}{l}\text { Value } \\
\text { Index }\end{array}$ & Category Values \\
\hline \multicolumn{4}{|c|}{ Information Accessibility } \\
\hline 1 & $\begin{array}{l}\text { Socialization intensity of Musrenbang } \\
\text { activities in detail }\end{array}$ & 58.80 & Less Satisfactory \\
\hline 2 & $\begin{array}{l}\text { Ease for the user to access information of } \\
\text { Musrenbang activities through Online } \\
\text { Musrenbang website }\end{array}$ & 60.80 & Satisfactory \\
\hline \multicolumn{4}{|c|}{ User interface design of the website } \\
\hline 3 & Interactive interface & 62.20 & Satisfactory \\
\hline 4 & $\begin{array}{l}\text { Functionality of feature for channeling } \\
\text { community aspiration }\end{array}$ & 64.60 & Satisfactory \\
\hline 5 & $\begin{array}{l}\text { Functionality of feature for the resource from } \\
\text { society }\end{array}$ & 39.80 & Unsatisfactory \\
\hline 6 & Functionality of feature for decision making & 47.00 & Less Satisfactory \\
\hline 7 & $\begin{array}{l}\text { Functionality of monitoring feature at the } \\
\text { implementation of Musrenbang }\end{array}$ & 39.80 & Unsatisfactory \\
\hline 8 & $\begin{array}{l}\text { Functionality of evaluation feature at the } \\
\text { implementation of Musrenbang }\end{array}$ & 37.60 & Unsatisfactory \\
\hline \multicolumn{4}{|c|}{ Usage of the website } \\
\hline 9 & Ease of application usage & 67.60 & Satisfactory \\
\hline 10 & Responsibility of application & 60.60 & Satisfactory \\
\hline 11 & Interaction with service officers (interactive). & 58.20 & Less Satisfactory \\
\hline \multicolumn{4}{|c|}{ Website Content } \\
\hline 12 & Reliability of presented information & 50.60 & Less Satisfactory \\
\hline 13 & Relevance to the topic of development & 47.00 & Less Satisfactory \\
\hline 14 & $\begin{array}{l}\text { Compatibility of Online Musrenbang with all } \\
\text { applicable regulations }\end{array}$ & 39.80 & Unsatisfactory \\
\hline 15 & Government appreciation for community & 42.00 & Less Satisfactory \\
\hline 16 & $\begin{array}{l}\text { Presentation of information on how to use } \\
\text { the application }\end{array}$ & 51.00 & Less Satisfactory \\
\hline 17 & Presentation of sustainable planning & 54.80 & Less Satisfactory \\
\hline 18 & $\begin{array}{l}\text { Presentation of community-focused planning } \\
\text { information }\end{array}$ & 55.60 & Less Satisfactory \\
\hline 19 & Presentation of feasibility planning & 55.80 & Less Satisfactory \\
\hline 20 & $\begin{array}{l}\text { Presentation of Musrenbang data } \\
\text { information }\end{array}$ & 39.60 & Unsatisfactory \\
\hline
\end{tabular}

The average overall index value is 51. This value falls within the Less Satisfactory category range. Thus, the design of online musrenbang related to this participatory planning process as a whole is identified as 'Less Satisfactory'.

\section{A. Information Accessibility}

The identification of the public satisfaction with the accessibility of information in this study is related to the intensity of socialization and information media (government website or other media) used for the dissemination of Musrenbang activities in detail at each stage referring to the current Online Musrenbang website and the ease of accessing information or data deals with Musrenbang activities through the Online Musrenbang website intensively and from a variety of gadgets.

The intensity and variety of dissemination media Musrenbang identified 'Less Satisfactory'. The community needs detailed information related to the implementation of the Musrenbang at each stage. The Government is obliged to 
inform all matters relating to the implementation of participatory planning for public knowledge [4]. Such information will improve the community's understanding of the planning process that will take place which will influence the increase of participation in participatory planning implementation.

The ease of accessing information or data related to Musrenbang activity through Online Musrenbang website (eMusrenbang) identified 'Satisfactory'. Such information can be accessed through various media and gadgets, although there has not been an android based app and SMS service. This is represented by the value of the satisfaction index which is at the lower limit of the range 60-79.9. Implementation of the broadest socialization, causing the community to participate actively in accordance with the objectives and agenda set and communicated through information systems that have been provided [10]. So it can affect the successful implementation of participatory planning.

Based on Table I, the satisfaction of the people on the quality of Online Musrenbang website design related to accessibility of information as a whole is identified as 'Less Satisfactory'.

\section{B. User Interface Design of The Website}

The identification of the public satisfaction with website design in this research is related to interactive interface display and feature functionality, among others related to the channeling of community aspiration, the resource from society, decision making, monitoring and evaluating features at the implementation of Musrenbang.

The interactivity interface of this web-based application was identified as 'Satisfactory'. The more interactive interface of the website will be increasing the user's desire to use the website [3]. The channeling of community aspiration was also identified as 'Satisfactory'. There is a community involvement mechanism starting from the RW level proposing 2 main proposals and 1 backup proposal through the 'Input Proposed' facility based on the 'Proposed Dictionary'. This is the way of close collaboration between planners and the people in development planning of the city [12]. Nevertheless, there are parts of both that according to respondents have not been facilitated such as, displaying proposals based on a particular RW and sort the list of proposals based on the particular proposal. Filter settings to show a list of proposals with specific criteria also cannot be save in softcopy format or print specifically provided by this application. Printing and saving process was using the facilities available on the browser. Those are reinforced by the value of satisfaction index which is at the lower limit of the range 60-79.9.

Public satisfaction to community involvement mechanism in this application related to the resource from society is identified as 'Unsatisfactory'. Community involvement through support in the form of resources, such as human resources, food support, income or other material incentives does not exist yet. Such this is part of community participation in the development process at the genuine participation stage [13]

The functionality of features related to the involvement of the community to determine the decision of the community proposals decided on this application is identified as 'Less Satisfactory'. The involvement of communities just starts from the RW level, not to individual level. In genuine participation, agreement and outcome of decision-making should be a collaboration between government and community to individual level [12].

While the involvement of the community in terms of reporting on deviations that occurred and evaluate the implementation of Musrenbang identified 'Unsatisfactory'. There is no community involvement in monitoring and evaluating the implementation of Musrenbang as a form of partnership between the division of responsibilities in the planning process which is part of the genuine participation stage. An inherent division of responsibility is required, as it will be able to produce better public services, better programs or projects or successful and sustainable initiatives [10].

Based on Table I, the satisfaction of the public regarding the quality of Online Musrenbang website design related to website design as a whole is identified as 'Less Satisfactory'.

\section{Usage of The Website}

The identification of the public satisfaction with the use of the website in this research is related to the ease of application usage, application responsibility and the interaction with the service officer (interactive)

Ease of application usage is identified as 'Satisfactory'. However, the existence of information is still difficult for the user to remember. This affects the value of the satisfaction index. That causes it is still at the lower limit of the range 6079.9. Use of an application should provide ease of operation and can be understood by the user [14]

The ability of this application in terms of responsiveness to the following inputs with input errors that may be performed by the user is identified 'Satisfactory'. But there are some parts that have not been facilitated. That made the value of satisfaction index is still at the lower limit of the range of 60-79.9. The level of application responsiveness is directly proportional to the quality of the website. The better the level of responsiveness of an application indicates web quality is good as well [14].

The quality of the facilities for handling community assistance requests was identified as 'Less Satisfactory'. The more interactive the website and the help services provided, the higher the user's desire to use the website [3]. In this app, the facility for interaction with the service officer (interactive) has not run properly.

Based on Table I, the public satisfaction on the quality of Online Musrenbang website design related to the usage of the website as a whole is identified as 'Satisfactory', with the average satisfaction index value is at the lower limit of the range of 60-79.9.

\section{The Website Content}

The identification of public satisfaction with the content or content of the website in this study is related to the reliability of the information presented, the relevance of the topics of the development planning, the Online Musrenbang (e-Musrenbang) conformity with all applicable regulations, and the government's appreciation of community participation in the planning process development. It is also related to the presentation of information on application usage, presentation of sustainable planning information, presentation of community-focused planning information, presentation of 
planning information, presentation of information related to Musrenbang organizing component.

The reliability of the information on the Online Musrenbang application (e-Musrenbang) and the relevance of that information to the identified 'Less Satisfactory' development plans. Similarly, the quality of information related to sustainable planning and satisfaction of information that can measure the focus of planning on society. Meanwhile, the quality of information related to the suitability of Online Musrenbang with all applicable laws or regulations identified as 'Unsatisfactory'. This is caused by no other information that can actually be presented related to the implementation of musrenbang other than the proposal. The reliability of the application in providing true and timely information and services influences the successful use of Online Musrenbang as e-government [16]. This application has not presented the information about realization time of the proposal received and the percentage of proposals received as development activities have not been facilitated in this application. So people can not know the focus of planning on society that is able to answer the needs and problems that faced by the community. Reliable and relevant information is needed to improve the public knowledge as well as its representatives of the planning process that will take place as part of community involvement can influence the implementation of participatory planning [17]. The information that must has relevance to the problems that faced by users so that it can make the benefit for users is one aspect of the website content quality that can affect to the successful implementation of participatory planning [14].

The quality of information related to the appreciation of the government regarding the active role and participation of the community in the participatory planning process in this application is identified as 'Less Satisfactory'. In this application, there is no such information. An appreciation of all efforts undertaken by the participant and minimizing any unpleasant incident should be done, in order to generate trust, satisfaction, and comfort for the community and stakeholders in the preparation of the development plan [17]. One way of rewarding that according to influence can raise public awareness of the importance of appropriate policymaking is incentives [18].

Whereas, the quality of information related to the way the application usage is identified as 'Less Satisfactory'. This facility is already available in this application, but the expected information has not been delivered holistically in accordance with the level of users who educate the community. So it can be easier to operate the application. An application must make it easy for users to learn that supported by the operation manual is part of the web content related to the use of the application [14]. Such convenience can improve their understanding of the planning process that will take place as part of community engagement, thus affecting the implementation of participatory planning [18].

The quality of information related to the feasibility of a plan is also identified as 'Less Satisfactory'. This application has not provided information regarding the suitability of planning with cost and time. As users should get this information in order to understand the planning process that will take place as part of community engagement may influence the implementation of participatory planning in Online Musrenbang as e-government. When forming of the planning program should be determined determination objectives plan is an expression of a value associated with future ideal conditions to be achieved within a certain time frame based on the constitution or legislation that has been established [19].

The quality of information related to Musrenbang identified components is 'Unsatisfactory'. This application has not provided that information thoroughly. The existence of an adequate source of information and communication facilities in an area will support the community in obtaining information about the implementation of development planning. So as to enable the community to be critical, initiative, creative, and dynamic and able to follow the process of change that occurred. [20]

Based on Table I, community satisfaction with the quality of Online Musrenbang website design related to the website content as a whole is identified as 'Less Satisfactory'.

\section{CONCLUSION}

The quality of Online Musrenbang design related to the participatory planning process as a whole is identified as 'Less Satisfactory'. Community satisfaction on the website design of Online Musrenbang quality from 4 research indicators was 3 identified as 'Less Satisfactory'. These indicators are the accessibility of information, user interface design of the website and the content of the website. Meanwhile, the usage of the website is identified as 'Satisfactory'.

There are 20 variables in this research which 5 variables that are categorized as 'Unsatisfactory', 10 variables are categorized as 'Less Satisfactory' and 5 variables are categorized as 'Satisfactory' with value index at the lower limit of the 'Satisfactory' category value range. Almost all the variables are not implemented in this web-based application or not run properly. Therefore, all variables can be categorized as the substation that needs to be developed to increase people's satisfaction with this application.

\section{REFERENCES}

[1] Idajati, H., Pamungkas, A., Siswanto, V., "Monitoring Efektivitas Participatory Planning Berbasis Online di Surabaya, Proceeding Seminar Nasional Eco City: Utopis Atau Realistis?", pp VII-55, 2014.

[2] Azhar, F., "Partisipasi Masyarakat Dalam Musyawarah Perencanaan Pembangunan (MUSRENBANG) di Kelurahan Pegirian Kecamatan Semampir Kota Surabaya. Kebijakan dan Manajemen Publik". Volume 3, No. 2, Mei-Agustus 2015, pp. 63, 2015.

[3] Qutaishat, F., Ahmed, S., Zaid, M., Al-Manasra, E. "The Effect of ERP Successful Implementation on Employees' Productivity, Service Quality and Innovation: An Empirical Study in Telecommunication Sector in Jordan", International Journal of Business and Management, Vol. 7, No. 19, pp. 45, 2012

[4] Satries, W. ,'Mengukur Tingkat Partisipasi Masyarakat Kota Bekasi Dalam Penyusunan APBD Melalui Pelaksanakaan Musrenbang 2010", Jurnal Keyberman, Vol. 2, No. 2, Sep 2011, pp. 99, 2011

[5] Sumarsono, Manajemen Keuangan Pemerintahan, Graha Ilmu, Yogyakarta, 2010

[6] Karbina, B., "The E-Participation Ladder - Advancing from Unawareness to Impact Participation, CeDEM16: Proceedings of the the International Conference for E-Democracy and Open Government", 1820 May 2016, University Krems, Danube, Austria, pp 75-84

[7] Muhajir, N., Metodologi Penelitian Kualitatif: Pendekatan Positivistik, Rasionalistik, Phenomenoligik dan Realisme Metaphisik, Telaah Study Teks dan Penelitian Agama, Rake. Sarasin, Yogyakarta, 2006.

[8] Sugiyono, Metode Penelitian Kuantitatif, Kualitatif, dan R \& D, Cetakan ke 19, Alfabeta, Bandung, 2013.

[9] Zainuddin, A., Metode Penelitian Hukum, Cetakan Ke-4, Sinar Grafika Jakarta, 2013 
[10] Mahmood, M., "Advancad Topics in End User Computing”, Volume 3, Idea Group Inc (IGI), 2013.

[11] Djaali dan Muljono, P., Pengukuran Dalam Bidang Pendidikan, PPS UNJ, Jakarta, 2004.

[12] Martín, P ., "Participation Schemas: a tool to characterize collaborative participation, PDD2014, Contemporarty difficulties and future prospects for Participatory and Deliberative Democracy", NewCastle, 9-11 July 2014.

[13] Hobley, M., "Participatory forestry: the process of change in India and Nepal, Rural development forestry guide three", Overseas Development Institute, London, 1996, pp. 1-24.

[14] Nielsen, J., Designing Web Usability: The Practice of Simplicity, New Riders Publishing, UK, 2003.

[15] Kumar,V., Mukerji,B., Butt,I., dan Persaud, A., " Factors for Successful e-Government Adoption: A Conceptual Framework, Electronic Journal of E-Government", Vol. 5, No. 1, 2009, pp. 63-76.
[16] Papadomichelaki, Xenia, "E-GovQual: A Multiple-Item Scale For Assessing e-Government Service Quality", National Technical University of Athens, Athens, 2011

[17] Menzel, S., Matthias, B., Tobias, S. (2013), dalam Idajati, H., Pamungkas, A., Siswanto, V., "Monitoring Efektivitas Participatory Planning Berbasis Online di Surabaya. Proceeding Seminar Nasional Eco City: Utopis Atau Realistis?", 2014, pp VII-55

[18] Berger, I., "The Demographics of Recycling and Structure of Environmental Behavior, Environment and Behavior", Vol. 29, No. 4, July 1997, pp. 515-531.

[19] Nasution, S., "Pengaruh Proses Perencanaan terhadap Kualitas Rencana Kerja Pemerintah Dalam Rangka Pelaksanaan Pembangunan Wilayah di Kota Binjai", Universitas Sumatera Utara, Medan, 2012.

[20] Kurniantara, Pratikno (2005), dalam Cahyani, R , "Partisipasi perempuan dalam kegiatan simpan pinjam kelompok perempuan (SPP) (kasus PNPM Mandiri perdesaan di salah satu desa di kabupaten Banyumas)". Institut Pertanian Bogor. Bogor, 2011. 